\title{
KONSEP PENGEMBANGAN \\ LINGKUNGAN PEMUKIMAN BERBASIS KOMUNITAS DI KAWASAN LAKKANG KOTA MAKASSAR
}

\author{
ROHANA \\ UNIVERSITAS MUHAMMADIYAH MAKASSAR \\ rohana@unismuh.ac.id
}

\begin{abstract}
ABSTRAK
Konsep Pengembangan Pemukiman Berbasis Komunitas di Kawasan Lakkang menjadi salah satu tujuan untuk memacu perkembangan sosial masyarakat dan mengurangi kesenjangan tata guna lahan yang tidak sesuai dengan peruntukannya. Menurut Chaprin, perencanaan wilayah (regional planning) adalah upaya intervensi terhadap kekuatan-kekuatan pasar dalam konteks pengembangan wilayah yang memiliki tiga tujuan pokok yakni meminimalkan konflik kepentingan antar sektor, meningkatkan kemajuan sektoral dan membawa kemajuan bagi masyarakat secara keseluruhan. Pengembangan Lingkungan Permukiman Berbasis Komunitas merupakan bentuk stimulan bagi keberhasilan masyarakat di Kelurahan Lakkang. Kegiatan tersebut secara substansi merupakan implementasi konsep bersama atau kemitraan dengan program skala yang kecil, seperti kelurahan. Melalui program tersebut, diharapkan terjadi proses pembelajaran, penataan dan kelembagaan mitra yang bersinergi antara masyarakat, pemerintah kelurahan dan kelompok sosial setempat. Dari beberapa penjelasan tersebut, terdapat beberapa masalah diantaranya: Bagaimana merencanakan pengembangan untuk membangun sarana dan prasarana yang baik, mewujudkan lingkungan fisik yang sehat, tertib, selaras dan mandiri serta nyaman? dan Bagaimana konsep pengembangannya, ditinjau dari aspek perencanaan?. Dari permasalahan tersebut, digunakan metode penelitian secara pembahasan, tahap pelaksanaan dan tahap kawasan prioritas. Sehingga diperoleh hasil: beberapa kondisi yang dilihat dari lokasi tersebut, secara umum struktur bangunan rumah di Kelurahan Lakkang adalah rumah tinggal yang bertipe bugis Makassar (panggung). Begitupun pada kawasan prioritas, mayoritas jenis rumah yang terdapat di kawasan prioritas ini adalah rumah panggung, namun sebagian masyarakat sudah merenovasi rumahnya dengan menambahkan ruang dibawah bangunan panggung sebagai bangunan tinggal permanen. Konsep pengembangannya ditinjau dari aspek perencanaan yang dikaji berdasarkan hasil analisis diatas, menghasilkan konsep Pengembangan Wilayah Terpadu, Konsep ini menekankan kerjasama antar sektor untuk meningkatkan kesejahteraan masyarakat dan penanggulangan kemiskinan di daerah-daerah tertinggal. Untuk menentukan daerah-daerah yang tertinggal, terdapat berbagai indikator yang digunakan, antara lain Perekonomian masyarakat, Sumber daya manusia Kemampuan finansial, Aksesibilitas; dan Karakteristik geografis.
\end{abstract}

Kata kunci: Kelurahan Lakkang, Komunitas, Konsep Pengembangan 


\section{PENDAHULUAN}

Konsep Pengembangan Pemukiman Berbasis Komunitas di Kawasan Lakkang Kota Makassar menjadi salah satu tujuan untuk memacu perkembangan sosial masyarakat pada kawasan tersebut dan mengurangi kesenjangan tata guna lahan yang tidak sesuai dengan peruntukannya. Menurut Chaprin, perencanaan wilayah (Regional Planning) adalah upaya intervensi terhadap kekuatan-kekuatan pasar yang dalam konteks pengembangan wilayah yang memiliki tiga tujuan pokok yakni meminimalkan konflik kepentingan antar sektor, meningkatkan kemajuan sektoral dan membawa kemajuan bagi masyarakat secara keseluruhan. Pada kawasan Lakkang tidak hanya menanggulangi kemiskinan secara lebih luas dan terpadu, tetapi juga memberi peluang bagi masyarakat Lakkang untuk menata kembali lingkungan hidup mereka dan mengembangkan tatanan sosial dan ekonomi mereka.

Penduduk Kelurahan Lakkang tahun 2014 tercatat sebanyak 1104 jiwa berdasarkan data Baseline 100-0-100 Tahun 2014. Terdiri dari 538 jiwa penduduk laki-laki dan 566 jiwa penduduk perempuan. Penyebaran penduduk Kelurahan Lakkang dirinci menurut RW, menunjukkan bahwa penduduk masih terkonsentrasi di wilayah RW 1 yaitu sebanyak 579 jiwa atau sekitar 51,27 $\%$ dari total penduduk, disusul RW 2 sebanyak 525 jiwa (48,73 \%). Bila ditinjau dari kepadatan penduduk Kelurahan Lakkang, RW 1 adalah terpadat yaitu 579 Jiwa/Km2, disusul RW 2, jumlah warga 525 jiwa per km persegi). Penyebaran penduduk masyarakat Lakkang, dapat dilihat pada peta kawasan sebagai berikut:

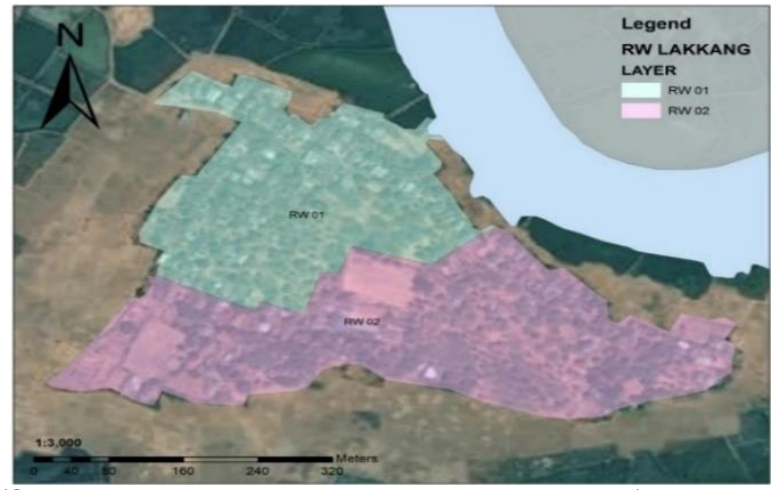

(Sumber: Laporan Akhir Pemerintah Kota Makassar), 2016
Gambar 1. Peta Administrasi Kelurahan Lakkang

Kelurahan Lakkang merupakan salah satu kelurahan penanganan, dengan luas kawasan prioritas adalah 13,36 Ha dan pada wilayah tersebut terdapat berbagai fungsi lahan, permukiman, fasum/fasos, persawahan, lahan kosong, dan empang. Kelurahan Lakkang memiliki berbagai sarana kesehatan seperti Puskesmas pembantu dengan luas $900 \mathrm{~m}^{2}$ yang terletak di sebelah kantor kelurahan Lakkang. Sedangkan berdasarkan standar Nasional Indonesia untuk Puskesmas pembantu dan balai pengobatan yang berfungsi sebagai unit pelayanan kesehatan sederhana yang memberkan pelayanan kesehatan terbatas dan membantu pelaksanaan kegiatan puskesmas dalam lingkup wilayah yang lebih kecil dan diperuntukkan bagi $=3.000$ jiwa dengaan luas lahan $\min =$ $300 \mathrm{~m}^{2}$.

Penyebaran penduduk Kelurahan lakkang tersebar pada kawasan permukiman yang berpola memanjang/linear mengikuti bentuk jalan. Penduduk yang tinggal di kawasan permukiman ini merupakan penduduk yang bekerja di bidang jasa dan perdagangan. Kawasan permukiman yang tersebar adalah dataran rendah dimana terkonsentrasi pada daerah

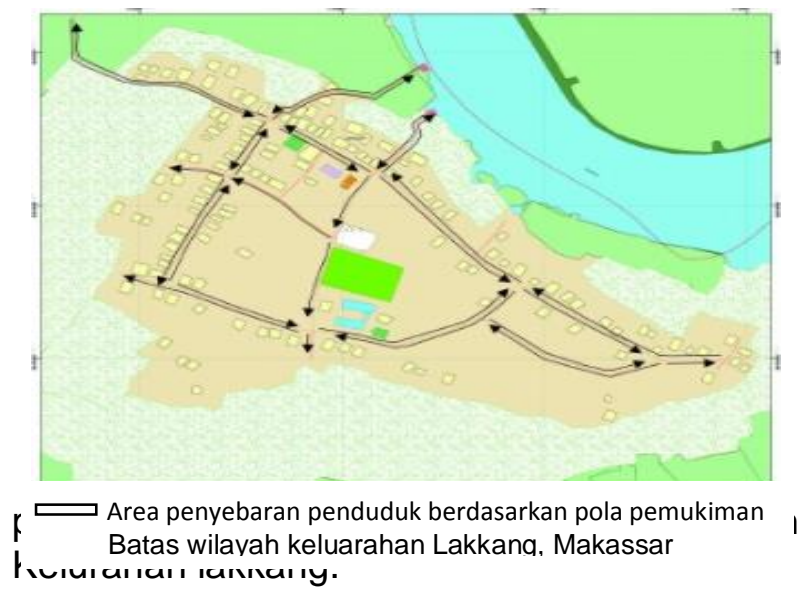

(Sumber: Laporan Akhir Pemerintah Kota Makassar), 2016 Gambar 2. Pola Penyebaran

Pengembangan Lingkungan Permukiman Berbasis Komunitas merupakan bentuk stimulan bagi keberhasilan masyarakat di Kelurahan Lakkang. Kegiatan tersebut secara substansi merupakan implementasi konsep 
bersama atau kemitraan dengan program skala yang kecil, seperti kelurahan. Melalui program tersebut, diharapkan terjadi proses pembelajaran, penataan dan kelembagaan mitra yang bersinergi antara masyarakat, pemerintah kelurahan dan kelompok sosial setempat. Prosesnya lebih mengutamakan pada swadaya, kemandirian dan kerja keras untuk menggalang segala potensi sumber daya yang dimiliki bersama dan mengakses berbagai sumber daya dari luar lainnya, dengan upaya mengembangkan lingkungan permukiman yang sehat, tertib, selaras, cerdas dan mandiri menuju cita-cita masyarakat yang sejahtera.

\section{PERMASALAHAN}

Berdasarkan beberapa penjelasan yang telah dikemukakan, maka dibuat rumusan masalah sebagai berikut: Bagaimana merencanakan pengembangan untuk membangun sarana dan prasarana yang baik, mewujudkan lingkungan fisik yang sehat, tertib, selaras dan mandiri, yang merupakan wujud dari kemajuan masyarakatnya dengan memberikan fasilitas yang aman dan nyaman? dan Bagaimana konsep pengembangannya, ditinjau dari aspek perencanaan?

\section{METODE PENELITIAN}

Dalam penelitian tersebut, ada beberapa metode dan tahapan yang dilakukan untuk menjawab permasalahan, diantaranya:

\section{Metode Pembahasan}

Untuk mencapai hasil yang diharapkan, maka salah satu strategi pelaksanaan yang digunakan adalah melalui pembangunan lingkungan sebagai pintu masuk dengan menciptakan manusia seutuhnya sehingga menghasilkan warga masyarakat yang secara sosial efektif dan secara ekonomi produktif, yang pada gilirannya akan membangun masyarakat adil, maju dan sejahtera. Strategi ini akan diwujudkan dengan 3 cara utama sebagai berikut:

Edukasi masyarakat dalam bentuk pembelajaran kritis, diskusi kelompok terarah, studi kasus, kunjungan lapangan, yang terkait dengan peningkatan kesejahteraan masyarakat, tata kepemerintahan/pelayanan publik, bencana alam.

Serangkaian musyawarah warga untuk menyepakati aturan pembangunan dan pengelolaan lingkungan, penataan ruang, penataan bangunan dan lingkungan, pelayanan publik.

Menggunakan pembangunan lingkungan sebagai media praktek untuk penataan tata laku yang positif dan efektif (etika pembangunan).

\section{Tahap pelaksanaan}

Terdapat beberapa tahapan pelaksanaan penataan lingkungan permukiman berbasis komunitas, yaitu:

Tahap Persiapan, Inti kegiatan dalam tahap ini adalah penetapan kawasan prioritas dan sosialisasi program melalui berbagai media dengan penekanan pada lokakarya orientasi program secara berjenjang dari tingkat nasional, propinsi dan daerah.

Tahap Perencanaan seperti survey Lapangan: Dalam pencarian data penulis melakukan survey lapangan, dimana datadata tersebut dalam bentuk foto dan sebagainya.

Wawancara (Persuasif): Selain survey lapangan, untuk memperoleh data yang lebih akurat penulis juga melakukan pendekatan terhadap warga dimana warga tersebut adalah selaku ketua RW dan RT maupun warga atau tokoh masyarakat tertentu dengan cara mewawancarai. Inti kegiatan pada tahap ini adalah membangun kolaborasi perencanaan dimana antar berbagai pihak (masyarakat, pemerintah dan pelaku usaha/swasta) dapat saling terbuka berbagi informasi, melakukan dialog dan konsultasi, dan bersepakat terhadap aturan bangunan setempat dan pokok - pokok perencanaan dan pembangunan.

\section{Tahap Kawasan Prioritas,}

Inti kegiatan pada tahap ini adalah melakukan proses kawasan yang akan ditata kembali dan telah tersedia RTPLP-nya (Rencana Tindak Penataan Lingkungan Permukiman) kepada berbagai pihak seperti antara lain dinas / instansi pemerintah (sumber dana APBN/APBD) maupun lembaga / instansi non pemerintah seperti lembaga bisnis, sosial, baik ditingkat nasional maupun multinasional sehingga terjadi kerjasama yang saling menguntungkan atau kontribusi sepihak seperti "channelling" dari dinas/sektor lain. 
Pada tahap ini juga akan dilakukan pelaksanaan pembangunan fisik untuk mencoba dan memantapkan manajemen pembangunan oleh komunitas.

\section{HASIL DAN PEMBAHASAN}

Dari beberapa metode dan tahapan yang dilakukan, diperoleh hasil:

Tahap Wilayah: Dalam konsep pengembangan pemukiman lingkungan, harus tetap memperhatikan sebuah fungsi dan tata guna lahan yang ada, sehingga sebuah bangunan yang nantinya benar-benar fungsional yang keberadaannya tidak mengganggu lingkungan di sekitarnya.

Tahap Materi: Pembahasan di tekankan pada disiplin ilmu arsitektur yang berkaitan dalam perencanaan dan perancangan sebuah desain penataan lingkungan pada wilayah tersebut.

Tahap Pencarian Data: Tahap ini dilakukan dengan mencari data-data yang dibutuhkan serta melakukan berbagai cara seperti survey langsung ke lapangan maupun menggunakan study literatur. Survei lapangan dilakukan untuk mendapatkan data-data secara langsung melalui pengamatan tentang kondisi tapak dan lingkungan sekitar. Studi Literatur merupakan studi yang diambil dari beberapa referensi sebagai landasan teori dan juga sebagai acuan dalam penyusunan, biasanya berupa peraturan-peraturan yang ada di kota tersebut maupun standar-standar yang harus diterapkan sebelum merancang suatu bangunan atau kawasan.

Tahap Analisa: Yaitu tahap penguraian dan pengkajian data yang disusun sebagai landasan yang mendasar bagi pendekatan perencanaan dan perancangan Penataan Lingkungan Permukiman Berbasis Komunitas (PLPBK).

Dari beberapa kondisi yang dilihat dari lokasi tersebut, secara umum struktur bangunan rumah di Kelurahan Lakkang adalah rumah tinggal yang bertipe bugis Makassar (panggung). Begitupun pada kawasan prioritas, mayoritas jenis rumah yang terdapat di kawasan prioritas ini adalah rumah panggung, namun sebagian masyarakat sudah merenovasi rumahnya dengan menambahkan ruang dibawah bangunan panggung sebagai bangunan tinggal permanen.
Selain dari pola struktur rumah yang masih terlihat tradisional bernuansa semi modern, terdapat juga pola kebiasaan masyarakat yang bersifat lebih mementingkan budaya kelompok sosial. Pengaruh budaya seperti ini akan menciptakan pengelompokan sosial, dimana pada umumnya masyarakat beretnis makassar dengan kebiasaan dan adat istiadat yang hidupnya berkelompok dan berkumpul pada sebuah lingkungan kecil akan mempengaruhi perkembangan wilayah mereka dengan konsentrasi budaya kelompok sosial yang bersifat statis, sehingga terbawa dan teraplikasikan dalam kondisi bermasyarakat saat ini.

Di Kelurahan Lakkang pada umumnya mata pencaharian pokok masyarakat di dominasi oleh pekerjaan nelayan dan petani dikarenakan kondisi geografis kelurahan Lakkang yang berada di sekeliling sungai Tallo. Sehingga jenis pekerjaan utama atau pokok yang ada adalah nelayan yaitu sebanyak $11.26 \%$ atau 34 jiwa. Sedangkan untuk para ibu-ibu hampir $100 \%$ berprofesi sebagai IRT.

Mengenai kondisi sarana dan prasarana di Kelurahan Lakkang sangat minim, disebabkan karena lokasi ini jauh dari jangkauan kota dan tidak ada jalur yang menghubungkan dengan jalan darat disebelah utara, Tmur, Selatan dan barat diapit sungai yaitu sungai Pampang dan sungai Tallo inilah penyebab utama sehingga sarana dan prasarana dikelurahan sangat minim. untuk lebih jelasnya dapat diurai

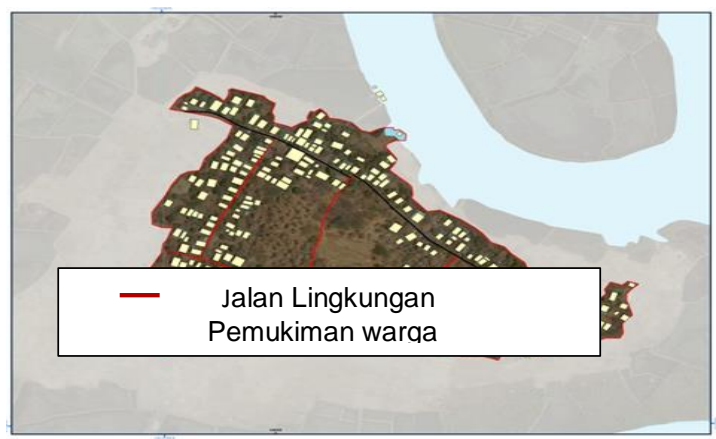

sebagai berikut :

(Sumber:Laporan Akhir Pemerintah Kota Makassar,2016)

Gambar 3. Perencanaan jalan lingkungan yang terorganisir 
Tabel 1. Aksesibiltas Lingkungan

\section{Konsep Dasar Perancangan Tata Bangunan dan Lingkungan Berbasis Komunitas}

Konsep dasar perancangan Tata Bangunan dan Lingkungan merupakan hasil tahapan analisis program bangunan dan lingkungan yang memuat gambaran dasar penataan pada lahan perencanaan yang selanjutnya ditindaklanjuti dengan penjabaran gagasan desain secara lebih detail dari masing-masing elemen desain.

\section{Visi Misi Pembangunan}

Visi :

"Mewujudkan hunian masyarakat terpadu terhadap kepedulian dan pemanfaatan lingkungan yang maksimal dengan pembangunan lingkungan di tahun 2019 “

Misi :

Peningkatan kualitas dan kuantitas saluran irigasi sebagai sarana dan meminimalkan bencana banjir.

Peningkatan kualitas dan kuantitas sarana dan prasarana jalan sebagai akses mobilitas warga.

Penempatan dan pengelolaan sampah yang dikelola dengan baik dan sehat

Pemanfaatan lahan pekarangan untuk tanaman produktif dan warung hidup pemanfaatan lahan-lahan terbuka secara maksimal sebagai Ruang Terbuka Hijau (RTH) dan taman desa/kegiatan publik.

Tabel 2. Konsep Pengembangan berdasarkan prosentase

\begin{tabular}{lccc}
\hline Alamat RT/RW & $\begin{array}{c}\text { Drainase } \\
\text { lingkungan }\end{array}$ & $\begin{array}{c}\text { Pengelolaan } \\
\text { Air Limbah }\end{array}$ & $\begin{array}{c}\text { Pelayanan } \\
\text { Air Minum }\end{array}$ \\
\hline RT001-RW001 & $0 \%$ & $90 \%$ & $5 \%$ \\
\hline RT001-RW002 & $0 \%$ & $93 \%$ & $0 \%$ \\
\hline RT002-RW001 & $0 \%$ & $100 \%$ & $91 \%$ \\
\hline RT002-RW002 & $0 \%$ & $83 \%$ & $0 \%$ \\
\hline RT003-RW001 & $100 \%$ & $100 \%$ & $0 \%$ \\
\hline RT003-RW002 & $0 \%$ & $100 \%$ & $0 \%$ \\
\hline RT004-RW001 & $0 \%$ & $52 \%$ & $0 \%$ \\
\hline RT004-RW002 & $0 \%$ & $68 \%$ & $20 \%$ \\
\hline RERATA & $13 \%$ & $86 \%$ & $15 \%$ \\
\hline SuTb: Da Ken
\end{tabular}

Sumber: Data Kelurahan Lakkang, 2015

Untuk konsep pengembangannya yang ditinjau dari beberapa aspek perencanaan yang telah dikaji berdasarkan hasil analisis diatas, menghasilkan konsep Pengembangan Wilayah Terpadu, Konsep ini menekankan kerjasama antar sektor untuk meningkatkan kesejahteraan masyarakat

dan

\begin{tabular}{|c|c|c|c|c|c|c|c|}
\hline \multirow[b]{2}{*}{$\begin{array}{l}\text { Alamat } \\
\text { RT/RW }\end{array}$} & \multicolumn{7}{|c|}{ AKSESIBILITAS LINGKUNGAN } \\
\hline & $\begin{array}{c}\text { Panjang } \\
\text { Total } \\
\text { Jaringan } \\
\text { Jalan } \\
\text { Lingkung } \\
\text { an } \\
\text { (Meter) }\end{array}$ & $\begin{array}{c}\text { Panjang } \\
\text { jalan } \\
\text { lingkunga } \\
\text { n lebar }> \\
1,5 \text { meter }\end{array}$ & \begin{tabular}{c|} 
Panjang \\
jalan \\
lingkungan \\
lebar $>1.5 \mathrm{~m}$ \\
permukaan \\
nya \\
diperkeras \\
(meter) \\
\end{tabular} & $\begin{array}{c}\text { Jangkauan } \\
\text { Jaringan } \\
\text { Jalan } \\
\text { Lingkunga } \\
\text { n yang } \\
\text { layak (\%) }\end{array}$ & \begin{tabular}{|c|} 
Panjang jalan \\
lingkungan \\
lebar $>1,5$ \\
meter yang \\
permukaan \\
nya diperkeras \\
dan tidak rusak \\
(meter) \\
\end{tabular} & $\begin{array}{c}\text { Panjang jalan } \\
\text { lingkungan } \\
\text { lebar }>1,5 \\
\text { meter yang } \\
\text { dilengkapi } \\
\text { sal. samping } \\
\text { jalan (meter) }\end{array}$ & $\begin{array}{c}\text { Jalan } \\
\text { sesuai } \\
\text { persyar } \\
\text { atan } \\
\text { teknis } \\
(\%)\end{array}$ \\
\hline $\begin{array}{l}\text { RT001- } \\
\text { RW001 }\end{array}$ & 572 & 305.00 & 267 & $47 \%$ & 178.00 & 0.00 & $16 \%$ \\
\hline $\begin{array}{l}\text { RTO01- } \\
\text { RWO022 }\end{array}$ & 827 & 527.00 & 0 & $36 \%$ & 125.00 & 0.00 & $8 \%$ \\
\hline $\begin{array}{l}\text { RTO02- } \\
\text { RW001 }\end{array}$ & 910 & 550.00 & 360 & $40 \%$ & 145.00 & 0.00 & $8 \%$ \\
\hline $\begin{array}{l}\text { RTO02- } \\
\text { RWO022 }\end{array}$ & 258 & 153.00 & 105 & $41 \%$ & 105.00 & 0.00 & $20 \%$ \\
\hline $\begin{array}{l}\text { RT003- } \\
\text { RW001 }\end{array}$ & 710 & 460.00 & 250 & $35 \%$ & 75.00 & 150.00 & $16 \%$ \\
\hline $\begin{array}{l}\text { RTO03- } \\
\text { RW002 }\end{array}$ & 752 & 476.40 & 476 & $63 \%$ & 201.40 & 0.00 & $13 \%$ \\
\hline $\begin{array}{l}\text { RT004- } \\
\text { RW001 }\end{array}$ & 676 & 267.00 & 226 & $33 \%$ & 91.00 & 0.00 & $7 \%$ \\
\hline $\begin{array}{l}\text { RTO04- } \\
\text { RW002 }\end{array}$ & 470 & 260.00 & 210 & $45 \%$ & 85.00 & 0.00 & $9 \%$ \\
\hline RERATA & 5,175 & 374.80 & 2,194 & $42 \%$ & 125.68 & 18.75 & $12 \%$ \\
\hline
\end{tabular}

penanggulangan kemiskinan di daerahdaerah tertinggal. Daerah atau wilayah yang tertinggal adalah daerah yang masyarakat serta wilayahnya relatif kurang berkembang dibandingkan dengan daerah atau wilayah lain dalam skala nasional. Untuk menentukan daerah-daerah yang tertinggal, terdapat berbagai indikator yang digunakan. Kementerian PDT menggunakan lima indikator sebagai dasar penentuan daerah tertinggal di Indonesia antara lain: Perekonomian masyarakat, Sumber daya manusia, kemampuan finansial, Aksesibilitas; dan karakteristik geografis.

Pengembangan ekonomi lokal dapat diwujudkan dengan mendorong berkembangnya kawasan-kawasan ekonomi produktif dengan mengoptimalkan faktorfaktor kunci pengembangan kawasan yang berdaya saing dengan tetap menekankan

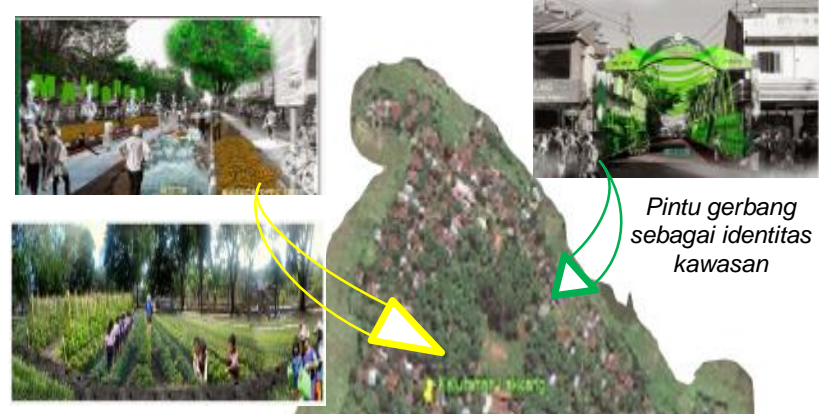
k*opedelaydintisiatif dan partisipasi masyarakat pogggaj pembentuk kitreatif dan produktif, peningkatan kualit@8ian) sumber daya manusia lokal, pemanfaatan sumber daya ekonomi, sosial, teknologi, dan kelembagaan lokal, serta penciptaan lapangan pekerjaan bagi penduduk dan masyarakat setempat. Dalam 
hal ini peranan pemerintah daerah dan atau kelompok-kelompok berbasis masyarakat (community based-groups) dalam mengelola sumber daya adalah berupaya untuk mengembangkan usaha kemitraan baru dengan pihak swasta, atau dengan pihak lain, untuk menciptakan pekerjaan baru dan mendorong berkembangnya berbagai kegiatan ekonomi.

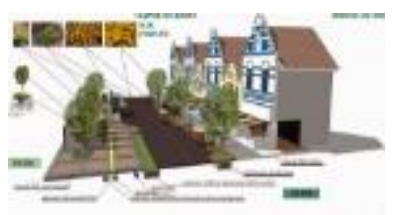

\section{KESIMPULAN}

Dari penelitian diperoleh kesimpulan :

Penataan Lingkungan Permukiman

Berbasis Komunitas yang dilaksanakan di kelurahan Lakkang, Kota Makassar dinilai berhasil dan sudah berjalan dengan baik. Evaluasi ini dilakukan dengan tiga analisis, yaitu:

Menganalisis pelaksanaan dengan pedoman teknis yang telah ditetapkan. Dari analisis diperoleh pelaksanaan kegiatan PLPBK di kelurahan Lakkang, telah sesuai dengan pedoman teknis yang telah ditetapkan. Evaluasi dengan mambandingkan Indikator Capaian Kinerja Program dengan realisasi, evaluasi yang diperoleh dengan indepth interview kepada stakeholder terkait dan masyarakat penerima manfaat dengan 4 indikator evaluasi yang ditanyakan, diperoleh kesimpulan bahwa kegiatn PLPBK sudah berjalan dengan baik dan memberikan manfaat kepada masyarakat di kawasan prioritas.

Dampak dari program PLPBK di kelurahan Lakkang, Kota Makassar yang dirasakan masyarakat miskin dan rentan dengan cara observasi langsung ke lapangan diperoleh kesimpulan bahwa program ini sangat dirasakan bermanfaat bagi masyarakat miskin dan rentan baik dari segi sosial dan ekonomi. Dengan indepth interview kepada masyarakat penerima manfaat diperoleh ratarata tingkat persepsi masyarakat terhadap dampak kegiatan PLPBK bermanfaat bagi masyarakat adalah lebih dari $80 \%$ telah meningkatkan kualitas infrastruktur permukiman dan sosial masyarakat di kawasan prioritas, sehingga dapat disimpulkan program PLPBK di kawasan prioritas dapat memberikan dampak ekonomi dan sosial masyarakat melalui penekanan jumlah pengeluaran untuk pembelian air bersih.

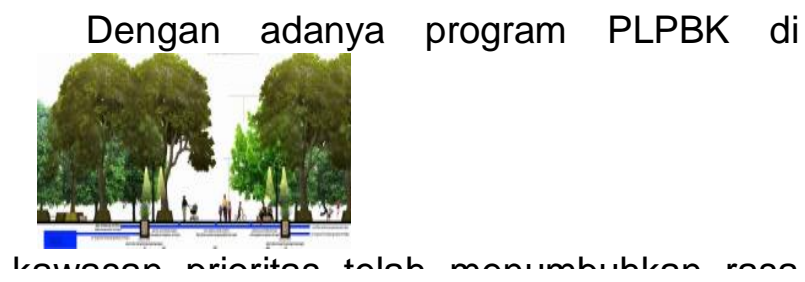

Gambar 4. Konsep pengembangan wilayah terpadu.

berorganisasi.

Dari hasil analisis, dapat dinilai bahwa metode ini dianggap berhasil, sehingga dapat dikembangkan sesuai dengan strategi-strategi yang telah dihasilkan dan disesuaikan dengan arah kebijakan dari pengembangan Rencana Tata Ruang Wilayah (RTRW) kota Makassar, yaitu:

Peningkatan kapasitas dari dokumen perencanaan partisipatif yang dihasilkan pada program PLPBK sebagai dokumen penjelasan RTRW kota Makassar untuk level kelurahan.

Mendorong masyarakat agar dapat menjalin kerjasama dengan pemerintah, swasta dan perorangan untuk menyalurkan CSR nya. Peningkatan koordinasi semua produk perencanaan yang ada di kota Makassar. Peningkatan kinerja dan semangat dalam melaksanakan program PLPBK, sehingga didapatkan hasil berkualitas. Percepatan pelaksanaan revisi Perda no.6 Tahun 2011 tentang RTRW Kota Makassar masalah penetapan lokasi RTH.

Pengembangan Konsep Wilayah Terpadu, menjadi efektif untuk diaplikasikan pada kawasan tersebut, karena wilayah demografinya sangat mendukung untuk membentuk citra kawasan menjadi wilayah percontohan untuk kawasan lainnya. Budaya kebersamaan dan kelompok sosial diantara mereka, menjadi arahan untuk membentuk 
kawasan tersebut menjadi lebih tertib, selaras dan mandiri. Sehingga faktor yang menentukan untuk mewujudkan konsep tersebut, dibutuhkan perhatian dari pihak pemerintah untuk mengintervensi mengenai penataan kawasan dan sosialisasi aktif mengenai peraturan pemerintah tentang wilayah-wilayah yang menjadi perencanaan/ penataan

kawasan. 


\section{DAFTAR PUSTAKA}

Adity, M. 2012. Perencanaan kelurahan lakkang menuju kawasan wisata berbasiskan kearifan lokal dan lingkungan yang layak huni (ekowisata), Perencanaan Wilayah dan Kota, Universitas Hasanuddin. Makassar.

Direktorat Pengembangan Permukiman, 2015. Panduan Penyusunan Strategi Pembangunan Permukiman dan Infrastruktur Perkotaan (SPPIP) dan Rencana Pembangunan Kawasan Permukiman Prioritas (RPKPP), Direktorat Jenderal Cipta Karya Kementerian Pekerjaan Umum.

Muliawan, A. 2011. Konsep Perencanaan dan Pengembangan Wilayah. http://awanpwk09.blogspot.co.id/2011/04/konsep-perencanaanwilayah_28.html, diakses 20 Desember 2016.

Mujimin. 2007. Penyediaan Fasilitas publik yang manusiawi bagi aksesibilitas difabel. Yogyakarta: Dinamika Pendidikan.

Prastowo, U. 2017, Penataan Lingkungan Permukiman Berbasis Komunitas di Desa Jomblang dan Tegalrejo, Dukuh, Sukoharjo dengan Pendekatan Green Architecture, Program Studi Arsitektur Fakultas Teknik Universitas Muhammadiyah Surakarta

Pemerintah Kota Makassar, 2015. Dinas Pariwisata dan Ekonomi Kreatif Potensi daya tarik Wisata Bahari kota makassar, Makassar

Primack, H.S., (1983), "Method of Stabilizing Polyvalent Solutions", U.S. Patent No. $4,373,104$.

Shirvani, H. (1985). The Urban Design Process. Jakarta: Erlangga.

Wandang, F. (n.d.). https://penulisinspirasi.blogspot.com/2014_11_01 archive, diakses 20 Desember 2016.

https://id.wikipedia.org/wiki/Lakkang,_Tallo,_Makassar, Profil Kelurahan Lakkang, diakses 20 Februari 2016. 